\title{
Common anti-oxidant vitamin $C$ as an anti-infective agent with remedial role on SARS-CoV-2 infection. An update
}

\author{
Christos Michailides, Dimitrios Velissaris \\ Department of Internal Medicine, University Hospital of Patras, Greece
}

\begin{abstract}
Coronavirus disease -2019 (COVID-19) has led to a worldwide multifaceted crisis. The medical world agonizes to contend with the problem, but a string of tested medications has been proven unavailing. Vitamin $\mathrm{C}$ is well described as a salutary antioxidant and some trials conclude that it may be a potential antiviral drug. In high doses, vitamin $\mathrm{C}$ can alternate crucial steps in the pathogenesis of sepsis and acute respiratory distress syndrome. This dynamic was the driving force behind trials around the world that tried immunonutrition as a weapon against clinical entities. We summarize the mechanisms of action of vitamin $\mathrm{C}$ and its role against infections and the current literature referring to the
\end{abstract}

\footnotetext{
Dimitrios Velissaris, Department of Internal Medicine, University Hospital of Patras, 26504 Patras, Greece.

Mobile: +30.6974909988 - Tel. +30 2610999583.

E-mail: dvelissaris@upatras.gr
}

Key words: SARS-CoV-2 infection; vitamin C; COVID-19 treatmen.t

Contributions: CM did literature search and wrote the paper, DV supervised and edited the paper. All the authors have read and approved the final version of the manuscript and agreed to be accountable for all aspects of the work.

Availability of data and materials: Available from the corresponding author upon reasonable request.

Ethics approval: Not applicable.

Financial support and sponsorship: No grants or funding were received.

Conflict of interest: The authors declare that there are not any conflicts of interest

Received for publication: 16 February 2021.

Accepted for publication: 26 May 2021.

${ }^{\circ}$ Copyright: the Author(s), 2021

Licensee PAGEPress, Italy

Monaldi Archives for Chest Disease 2021; 91:1808

doi: 10.4081 monaldi.2021.1808

This article is distributed under the terms of the Creative Commons Attribution Noncommercial License (by-nc 4.0) which permits any noncommercial use, distribution, and reproduction in any medium, provided the original author(s) and source are credited. potential role of vitamin $\mathrm{C}$ in SARS-CoV-2 infection, also as a contingent treatment agent.

\section{Introduction}

While COVID-19, a pandemic caused by SARS-CoV-2 [1], is spreading throughout the world, humanity is struggling to confront an intractable situation. The effort to discover a coronavirusspecific medication has drawn into a blind alley and among all tested treatments mostly corticosteroids seem to be salubrious for patients, additionally to standard care [2]. Meanwhile, the vaccination process is slow-burning, despite the promising published results $[3,4]$. Thus, there is an urgent need to approach new prospects pertaining to possible treatments.

This review is setting out to surface the use of ascorbic acid, a much-debated antioxidant substance, to counter some nodal COVID-19 pathophysiologic procedures. These procedures, including micro-thrombosis, cytokine storm and -au contraireimmunoparalysis, are described in terms of causing pneumonia, ARDS, sepsis and tissue damage, leading to ICU transmission and need for mechanical ventilation. Another important pathway includes macrophage hyperactivation, leading to hyperinflammatory response and nitric oxide increase. Along with the oxidative stress caused due to the severity of the disease, NO is oxidized to toxic metabolites, iron contained in hemoglobin is oxidized from the ferrous to the ferric form, leading to methemoglobinemia, and CRP and LDH are increased. That leads to oxidant-antioxidant imbalance and hypoxia [5-7]. Patients with COVID-19 pneumonia, hypoxia and ARDS have a very low $\mathrm{P} / \mathrm{F}$ index. Hence, they are in great need of high $\mathrm{FiO}_{2}$ levels and possible mechanical ventilation respiratory support [8-10]. Furthermore, we report the multiple physiologic pathways in which vitamin $\mathrm{C}$ takes place, such as oxidant balance and immune response. Also, we ratiocinate why immunonutrition and specifically vitamin $\mathrm{C}$ has been tried for the treatment of many diseases, such as common cold, sepsis and cancer, detailing some promising results. Finally, we dissect the results of the most relevant clinical trials that show a benefit in using high dose intravenous vitamin $\mathrm{C}$ against COVID19 complications and try to infer its optimal position in everyday clinical practice.

\section{Methods}

We conducted a PubMed search using the terms SARS-CoV2 infection and/or COVID-19 and vitamin C to identify all relevant publications. All type of the identified published articles and their references were searched for additional related articles. Only English written articles were finally included. 


\section{Results}

The major studies referring to COVID-19 and Vitamin $\mathrm{C}$ are presented in Table 1. The general outcome of the studies about VC therapies is that it is safe [11] and efficient at some points. The most hopeful results are the great survival percentage when used as last option [7] and a very high recovery rate presented by Burugu et al. [12]. Additionally, the researchers have described an improvement on $\mathrm{SpO}_{2}$ [11], body temperature [10,11], symptomatic-free days, in-hospital days, total bilirubin, IL-6 plasma levels [13], SOFA score, $\mathrm{P} / \mathrm{F}$ ratio [10, 13], ferritin plasma levels [9,12], CRP, CD-4 count, LDH [13], D-dimers [9,10] met-Hb and NO toxic metabolites after HDIVC administration [7]. On the other hand some studies did not show specific benefits after usage of vitamin c [14]. The aforementioned results are important because they are pertinent with the findings that VC plasma levels in COVID-19 patients are decreased or undetectable [15-17] and oxidant status is altered [17].

\section{Discussion}

\section{Vitamin C: mechanisms of action and immunomodulatory effects}

Vitamin C (VC) is well described as a great water-soluble compound, which resides in plasma and cells [18], participating in many crucial physiologic functions in the human body $[19,20]$. Vitamin C acts as a co-factor for the biosynthesis of norepinephrine, cortisol and carnitine and plays a key role in collagen hydroxylation and synthesis by osteoblasts, hypoxia induced factor (HIF) hydroxylation and regulation, vasopressin and cholecystokinin activity regulation, tyrosine metabolism and histone de-methylation [21-23]. Some additional properties, which are in reviewer's concern, are VC's antioxidant activity and its entrenchment to several anti-inflammatory and immunological proceedings [21]. As an antioxidant, ascorbic acid scavenges free radicals and oxidant products actualized via increasing nitric oxide (NO) by recycling tetrahydrobiopterin, suppressing NADPH oxidase and enhancing NO synthase (NOS) activity and, at a manifold concentration, superoxide dismutase activity to inactivate superoxide, which otherwise blocks NO [24,25]. VC can also regenerate glutathione, $\alpha$ tocopherol, urate and $\beta$-carotene [26]. Consequently, it prevents reactive nitrogen species production, leading to vessel relaxation and improving sepsis-induced decrease of capillary blood flow $[27,28]$. Additionally, ascorbic acid protects from DNA, lipids and proteins oxidation [26]. Thus, VC is influential in protection against diseases caused by oxidative stress [19].

Vitamin $\mathrm{C}$ has also a role in altering inflammatory response and modulating the immune system, which can be described by the term "immunonutrition". There is a lot of discussion about the role of some nutrients in medical daily practice but herein we present the evidence of VC capability of shifting some pathophysiologic tracts. First of all, VC is effective on innate immune system by reinforcing the maintenance of the alveolar epithelial barrier, affecting lipid synthesis and regulating the alveolar fluid clearance by potentiating cystic fibrosis trans-membrane conductance regulator (CFTR) and epithelial sodium channel $(\mathrm{ENaC})$ as shown in mice models [29,30]. Interestingly, $\mathrm{VC}$ can regulate polymorphonuclears (PMN) motility and phagocytosis, chemotaxis and Tcell maturation and development additionally to an increase in lymphoproliferative capacity $[21,22,31]$ as shown in some guinea pig experiments [32]. It is also proved that VC can decrease leukocyte fragility in guinea pig models [33]. Ascorbic acid's effect on chemotaxis may result from detoxifying histamine in vivo and decreasing histamine levels [34 35]. Furthermore, it is of great interest that $\mathrm{VC}$ is contributing to regulate NETosis [36]. Neutrophil endothelial traps (NETs) is a mechanism to kill pathogens, though they can cause endothelial damage and they are a core pathogenetic mechanism in sepsis-related multiple organ failure [37]. Another major VC potentially beneficial aspect is its ability to regulate the immune balance. According to a study on healthy volunteers, $1 \mathrm{~g} / \mathrm{d}$ VC for 75 days increased $\operatorname{IgA}$, IgM and $\mathrm{C} 3$ levels [38]. Experiments in mice have demonstrated that $\mathrm{VC}$ can attenuate pro-inflammatory cytokines such as GM-CSF and $\mathrm{NF} \kappa \mathrm{B}$, regulating their pathways maybe due to reactive oxygen species (ROS) suppression, with potential effect on IL-5 reduction. Ascorbic acid can also bate immunosuppressive factors, such as TGF- $\beta$, IL-10 and CTLA-4 [29,39-42]. This happens basically due to dose-dependent VC blockage on TNF- $\alpha$-induced NFKB activation and agrees with a study that showed decreased cytokine activity in cancer patients after intravenous VC administration $[43,44]$. VC can encounter as well micro-vascular thrombosis caused by cytokine activation of coagulase cascade during sepsis $[29,42]$. Last but not least, VC could confront IL-7 mediated ACE2 increase [45] and endothelin-induced IL-6 increase [46].

\section{Vitamin C dosage}

Plasma level of Vitamin $\mathrm{C}$ below $11 \mu \mathrm{mol} / \mathrm{L}$ is considered a deficiency, between $11-23$ or $28 \mu \mathrm{mol} / \mathrm{L}$ is marginal and is characterized as hypovitaminosis while the optimal level is equal to or above $50 \mu \mathrm{mol} / \mathrm{L}$, which is rarely observed in COVID-19 patients [47-51]. Based on randomized trials, the optimal way of administration is every 6 hours, which can produce steady plasma levels quickly, correct plasma deficiency, normalize neutrophil ascorbic acid levels, provide an appropriate dosing schedule and maintain normal values [52,53], even in septic patients who turn out to have hypovitaminosis or deficiency despite attempts of standard nutrition. Another RCT [54] demonstrates that $2 \mathrm{~g} / \mathrm{d}$ can normalize plasma levels and $10 \mathrm{~g} / \mathrm{d}$ can achieve supranormal levels. Doses below $1 \mathrm{~g} / \mathrm{d}$ orally or $200 \mathrm{mg} / \mathrm{kg} / \mathrm{d}$ parenterally did not cause any adverse effects $[52,54,55]$.

\section{Vitamin C against infections}

Based on its biology and profitable effects on the human body, Vitamin $\mathrm{C}$ has been tried for the prevention and treatment of viral infections and the discussion about the possible benefits is longlasting. One of the first hopeful prospects was the use of Vitamin $\mathrm{C}$ against common cold to reduce incidence, duration and severity of symptoms. Some RCTs [56-58] used oral daily doses (50-150 $\mathrm{mg}$ for 5 years, $1 \mathrm{~g}$ for 8-16 weeks) and agreed on reduced incidence and severity but disagreed on the effect on the duration of symptoms. Other trials $[59,60]$ used high oral doses $(3 \mathrm{~g} / \mathrm{d})$ to treat common cold and flu but the results were polar opposite. A metaanalysis [61] suggests that $\mathrm{VC}$ dosage $\geq 2 \mathrm{~g} / \mathrm{d}$ reduces cold duration by $8 \%$, reduces the severity of symptoms and lowers the prevalence in high-risk populations, but not in the general population. In favor of VC antiviral activity were also some studies that used it orally combined with other antioxidants or alone to treat HSV, HIV or EBV and according to the results observed, they proposed a potential impact on viral replication [62-64].

Another possible role of $\mathrm{VC}$ is the usage in treating critically ill patients with sepsis, septic shock, ARDS and patients in need of 
Table 1. Studies referring to vitamin C and COVID-19.

\begin{tabular}{|c|c|c|c|c|c|}
\hline Study title & Author & Publication date & Study type & Intervention & Main outcomes \\
\hline $\begin{array}{l}\text { Effect of high-dose zinc } \\
\text { and ascorbic acid } \\
\text { supplementation } v s \\
\text { usual care on symptom }\end{array}$ & $\begin{array}{l}\text { Suma Thomas } \\
\text { et al. [14] }\end{array}$ & February 12, 2021 & $\begin{array}{l}\text { Randomized Controlled } \\
\text { Trial (RCT) }\end{array}$ & $\begin{array}{l}\text { Comparison between } 6 \mathrm{~g} \\
\text { VC, Zinc, both and } \\
\text { control group in } \\
\text { outpatients }\end{array}$ & $\begin{array}{l}\text { No significant primary or } \\
\text { secondary outcomes achieved } \\
\text { (symptoms, hospitalization, } \\
\text { deaths reduction) }\end{array}$ \\
\hline
\end{tabular}

length and reduction

among ambulatory

patients with

SARS-CoV-2 infection:

The COVID A to Z

randomized clinical trial

\begin{tabular}{|c|c|c|c|c|c|}
\hline $\begin{array}{l}\text { Safety and effectiveness } \\
\text { of high-dose vitamin C } \\
\text { in patients with COVID-19: } \\
\text { a randomized open-label } \\
\text { clinical trial }\end{array}$ & $\begin{array}{l}\text { Jamali Moghadam } \\
\text { Siahkali et al. [11] }\end{array}$ & February 11, 2021 & $\begin{array}{l}\text { Randomized Controlled } \\
\text { Trial (RCT) } \\
\text { plus HCQ }\end{array}$ & $\begin{array}{l}\text { Addition of } 6 \mathrm{~g} / \mathrm{d} \text { to } \\
\text { Lopinavir/Ritonavir } \\
\text { no adverse effects }\end{array}$ & $\begin{array}{l}\text { Improvement on day } 3 \mathrm{SpO}_{2} \\
\text { and body temperature, }\end{array}$ \\
\hline $\begin{array}{l}\text { The Role of Vitamin C } \\
\text { as Adjuvant Therapy } \\
\text { in COVID-19 }\end{array}$ & Kumari et al. [13] & November 30, 2020 & $\begin{array}{l}\text { Randomized Controlled } \\
\text { Trial (RCT) }\end{array}$ & $\begin{array}{l}\text { Addition of } 50 \mathrm{mg} / \mathrm{kg} / \mathrm{d} \\
\text { VC to standard therapy }\end{array}$ & $\begin{array}{l}\text { Improvement on symptomatic- } \\
\text { free days }(7.1+/-1.8 \text { vs } 9.6+/- \\
2.1) \text { and days in hospital } \\
(8.1+/-1.8 \text { vs } 10.7+/-2.2)\end{array}$ \\
\hline $\begin{array}{l}\text { Pilot trial of high-dose } \\
\text { vitamin C in critically ill } \\
\text { COVID-19 patients }\end{array}$ & Zhang et al. [8] & January 9, 2021 & Pilot trial & $12 \mathrm{~g} / \mathrm{d}$ IVC & $\begin{array}{l}\text { Improvement on SOFA scora, } \\
\text { total bilirubin, IL- } 6 \text { and P/F } \\
\text { ratio }\end{array}$ \\
\hline $\begin{array}{l}\text { Serum levels of vitamin C } \\
\text { and vitamin D in a cohort } \\
\text { of critically ill COVID-19 }\end{array}$ & Arvinte et al. [15] & December 8, 2020 & Pilot study & & $\begin{array}{l}\text { VC plasma levels are reduced } \\
\text { in critically ill COVID-19 } \\
\text { patients }\end{array}$ \\
\hline
\end{tabular}

patients of a North

American Community

Hospital Intensive Care

Unit in May 2020

\begin{tabular}{|c|c|c|c|c|c|}
\hline $\begin{array}{l}\text { Vitamin C levels in } \\
\text { patients with SARS- } \\
\text { CoV-2-associated acute } \\
\text { respiratory distress } \\
\text { syndrome }\end{array}$ & $\begin{array}{l}\text { Chiscano-Camón } \\
\text { et al. [16] }\end{array}$ & August 26, 2020 & $\begin{array}{l}\text { Prospective cohort } \\
\text { study }\end{array}$ & & $\begin{array}{l}17 \text { of } 18 \text { COVID- } 19 \text { patients } \\
\text { included had undetectable VC } \\
\text { plasma evels and } 1 \text { of } 18 \\
\text { patients had low VC plasma } \\
\text { levels }\end{array}$ \\
\hline $\begin{array}{l}\text { Oxidative stress status } \\
\text { in COVID-19 patients } \\
\text { hospitalized in intensive } \\
\text { care unit for severe } \\
\text { pneumonia }\end{array}$ & Pincemail [17] & February 7, 2021 & Pilot study & & $\begin{array}{l}\text { VC was low and oxidative stress } \\
\text { status was altered }\end{array}$ \\
\hline $\begin{array}{l}\text { Application of methylene } \\
\text { blue -vitamin C-N-acetyl } \\
\text { cysteine for treatment } \\
\text { of critically ill COVID-19 } \\
\text { patients }\end{array}$ & Alamdari et al. [7] & October 15,2020 & $\begin{array}{l}\text { Report of phase-I } \\
\text { clinical trial }\end{array}$ & $\begin{array}{l}\text { VC } 1500 \mathrm{mg} / \mathrm{kg} / \mathrm{d} \text { plus } \\
\text { methylene-blue plus } \\
\mathrm{N} \text {-acetylcysteine }\end{array}$ & $\begin{array}{l}\text { Reduction of } \\
\text { methemoglobinemea, NO toxic } \\
\text { metabolites, survival of } 4 \text { of } 5 \\
\text { patients who received MCN as } \\
\text { last option }\end{array}$ \\
\hline $\begin{array}{l}\text { Activities of serum } \\
\text { ferritin and treatment } \\
\text { outcomes among } \\
\text { COVID-19 patients } \\
\text { treated with vitamin C } \\
\text { and dexamethasone }\end{array}$ & Burugu et al. [12] & November 11, 2020 & $\begin{array}{l}\text { Uncontrolled } \\
\text { Single-Center } \\
\text { Observational Study }\end{array}$ & VC plus dexamethasone & $\begin{array}{l}94 \% \text { recovery rate, ferritin } \\
\text { reduction }\end{array}$ \\
\hline $\begin{array}{l}\text { Beneficial aspects } \\
\text { of high dose intravenous } \\
\text { vitamin C on patients } \\
\text { with COVID-19 pneumonia } \\
\text { in severe condition }\end{array}$ & Zhao et al. [10] & November 17, 2020 & $\begin{array}{l}\text { Retrospective case } \\
\text { series study }\end{array}$ & $\begin{array}{l}\text { HDIVC (median } 162,7 \\
\mathrm{mg} / \mathrm{kg} \text { to severe, median } \\
178,6 \mathrm{mg} / \mathrm{kg} \text { to critical } \\
\text { patients) }\end{array}$ & $\begin{array}{l}\text { Improvement on CRP, } \\
\text { temperature, CD4+ count } \\
\text { cells, P/F ratio, D-dimers, LDH, } \\
\text { SOFA score }\end{array}$ \\
\hline $\begin{array}{l}\text { The use of IV vitamin C } \\
\text { for patients with } \\
\text { COVID-19 }\end{array}$ & Hiedra et al. [9] & May 15,2020 & Case-series & $\begin{array}{l}\text { VC } 1 g \text { tid, plus } \\
\text { methylprednisolone- } \\
\text { HCQ-tocilizumab }\end{array}$ & $\begin{array}{l}\text { Reduction of ferritin } \\
\text { and D-dimers }\end{array}$ \\
\hline
\end{tabular}


mechanical ventilation. These patients are found to have deficiency or hypovitaminosis $\mathrm{C}$ and in ICU patients VC supply is insufficient but high dosage intravenous Vitamin C (HDIVC) can fix plasma levels $[52,65,66]$. Patients with low $\mathrm{VC}$ in plasma tend to have more increased CRP but HDIVC administration could reduce CRP, procalcitonin and SOFA score. One RCT [67] examined the enteral administration of eicosapentaenoic acid plus $\gamma$-linoleic acid plus antioxidants including VC against standard diet in patients with severe sepsis and shock in need of mechanical ventilation and resulted in an improvement on oxygenation status, ventilation-free days, ICU-free days, less organ dysfunctions, and decreased mortality rates. Two RCTs $[68,69]$ used VC $1.5 \mathrm{~g}$ every 6 hours plus thiamine plus hydrocortisone IV, one of them combined them with standard treatment vs standard treatment alone for sepsis and septic shock and the other compared them to hydrocortisone alone to treat sepsis. None of them achieved primary outcomes. The first showed an improvement on vasopressor administration duration and lactate clearance but failed to achieve its primary outcome, inhospital mortality and all the other secondary outcomes including SOFA score improvement. The second one also failed to achieve its primary outcomes, vasopressor-free days and time alive but resulted on an improved day-3 SOFA score. An additional RCT [52], which used a combination of parenteral antioxidants, including $1 \mathrm{~g} / \mathrm{d}$ bolus, in patients with septic shock, achieved to change hemodynamic parameters and established that $\mathrm{VC}$ and vitamin $\mathrm{E}$ could have synergistic action. VC could also augment quercetin antioxidant and antiviral properties and may have synergistic action with glycyrrhizic acid [70,71]. Combinations containing selenium and ascorbic acid, preferably parenteral, may be associated with decreased mortality in critically ill patients [39]. CITRIS-ALI [72] was a RCT in which HDIVC (50mg/kg) every 6 hours for 96 hours was administered to ICU-patients with sepsis and ARDS within the first 24 hours since sepsis and ARDS onset. Control group received placebo. In spite of not achieving any primary outcome (SOFA, CRP and thrombomodulin as indexes of organ failure, inflammation and vascular injury), this trial rendered some promising results. 28-day mortality was $29.8 \%$ in VC group and $46.3 \%$ in placebo group, ventilation-free days were $13.1 \mathrm{vs}$ 10.6, ICU-free days at day 28 were 10.7 vs 7.7 and hospital-free days at day 60 were 22.6 vs 15.5. Meta-analyses on this subject have been also designed. Enteral immunonutrition for ARDS is not supported $[73,74]$ but VC can reduce mortality and vasopressor use duration in patients with sepsis [75]. What is more, two metaanalyses by Hemila described that VC can reduce $7.8 \%$ the ICUstay and by $14 \%$ the needed mechanical ventilation. Benefit seems to be proportionate to ventilation time needed, severity of the disease and ICU time spent. No difference was found between enteral and parenteral administration $[76,77]$.

\section{Vitamin C and COVID-19}

Vitamin $\mathrm{C}$ has been found to be low or undetectable in critically ill patients with COVID-19 associated ARDS in ICU patients and along with age are co-dependent factors for mortality [15-17]. It is also noteworthy the effects of VC on COVID-19 co-morbidities (protective role in pathogenesis of cardio-vascular disease, reducing inflammatory and metabolic markers of hypertensive and diabetic obese patients, kidney protecting, anti-cancer properties) [78-80]. Numerous studies on COVID-19 patients are on the way and some of them have already provided hopeful results, largely arising from VC's influence on disease markers such as bilirubin, d-dimers, C-reactive protein (CRP), ferritin, lactate dehydrogenase (LDH), also on $\mathrm{PO}_{2} / \mathrm{FiO}_{2}(\mathrm{P} / \mathrm{F})$ index and Sequential Organ Failure Assessment (SOFA) score. HDIVC (11 g/d) availed a 74-year-old woman with ARDS in mechanical ventilation days and ICU stay compared to other patients in the same setting [81], while a 77year-old woman with ARDS had a rapid worsening after lowering the dose of VC from $6 \mathrm{~g}$ twice daily to $1 \mathrm{~g}$ once daily IV [82]. In a case series, 6 critically ill patients were treated with a mean 178.6 $\mathrm{mg} / \mathrm{kg} / \mathrm{d}$ dose and 6 severe ill patients with a mean $162.7 \mathrm{mg} / \mathrm{kg} / \mathrm{d}$ dose VC as rescue therapy on aggravation of symptoms of pneumonia and an improvement on inflammatory response (decreased $\mathrm{CRP}$, temperature), immune response (increased CD4+ cells) and organ function (decreased $\mathrm{P} / \mathrm{F}$ ratio, d-dimers, $\mathrm{LDH}$ and SOFA score) were observed [10]. In another case series a statistically insignificant decrease on oxygen requirement and a statistically significant decrease in ferritin and d-dimers were observed in 17 patients on mechanical ventilation when treated with $1 \mathrm{~g} \mathrm{IVC}$ every $8 \mathrm{~h}$ for 3 days [9]. An uncontrolled observational study used dexamethasone and VC combination to treat COVID-19 in-hospital patients and noticed a remarkably high recovery rate of $94 \%$. This study screened patients' ferritin as an index of macrophage activity-related cytokine storm. The mean serum ferritin levels among recovered and expired patients were $478.81 \mathrm{ng} / \mathrm{ml}$ and 1410 $\mathrm{ng} / \mathrm{ml}$, respectively, suggesting that ferritin could be a prognostic marker of the response to HDIVC [12]. The report of a phase-I clinical trial suggests that VC of a dosage $1500 \mathrm{mg} / \mathrm{kg} / \mathrm{d}$ combined with $\mathrm{N}$-acetyl-cysteine and methylene-blue (MCN) can improve $\mathrm{CRP}$ and LDH serum values and may reduce NO toxic metabolites, methemoglobin and oxidative stress in critically ill COVID-19 patients. This trial used $\mathrm{MCN}$ as rescue therapy for 5 patients and 4 of them survived [7]. A RCT compared standard therapy plus 50 $\mathrm{mg} / \mathrm{kg} / \mathrm{d}$ IVC and standard therapy alone. There was statistically significant difference in symptomatic-free days $(7.1 \pm 1.8 \mathrm{vs}$ $9.6 \pm 2.1$ days $)$ and in-hospital days $(8.1 \pm 1.8$ vs $10.7 \pm 2.2$ days $)$ between VC group and control group but there was not statistically significant benefit in \%-needed mechanical ventilation (16 vs $20 \%$ ) and mortality (9.3 vs $14.6 \%$ ) [14]. A multi-center pilot RCT compared HDIVC group ( $12 \mathrm{~g}$ twice a day for 7 days) with a placebo group of COVID-19 ARDS ICU patients. The primary outcome was invasive mechanical ventilation free days at day 28 and was not achieved (26.0 vs 22.0 days). 28-day mortality and ICU mortality were reduced in more severe patients. Total bilirubin was better in HDIVC group at day $3(8.4 v s 14.9 \mu \mathrm{mol} / \mathrm{L})$. The median SOFA score was improved (from 3.5 to 3 ) in the HDIVC group and worsened ( 2 to 6$)$ in the control group on day 7 . During the treatment period, $\mathrm{P} / \mathrm{F}$ was $228.5 \mathrm{mmHg}$ in the HDIVC group and 150.7 $\mathrm{mmHg}$ in the control group. IL-6 levels were also improved [8]. An open label RCT compared lopinavir/ritonavir plus hydroxychloroquine plus VC (6 g/d) to lopinavir/ritonavir plus hydroxychloroquine alone. The administration was proven safe, but the only significant outcomes were an improvement on $\mathrm{SpO}_{2}$ at day 3 since admission and a lower day-3 temperature for the VC group [11] The effect of VC $(8 \mathrm{~g})$ on reducing COVID-19 symptoms was examined by another RCT, which found no significant improvement on symptoms of VC group [14].

There are only a few case reports of major adverse effects after HDIVC, describing acute oxalate nephropathy [83] and acute kidney injury (AKI) with acute tubular injury (ATI) noted in biopsy of two patients [84]. Inferentially, HDIVC is safe and cost-effective at least as rescue therapy.

Based on above, some consensuses have already established protocols for the position of VC in everyday clinical practice. $\mathrm{MATH}+$ protocol suggests that methylprednisolone, ascorbic acid, thiamine and heparin should be administered as soon as possible since oxygen supplementation is needed to avoid ICU transmission [85]. Two other protocols suggest that patients should be screened 
for nutritional deficits since their admission to hospital to receive early nutritional support that consists of multiple vitamins, including $\mathrm{VC}$, due to their anti-inflammatory and antioxidant related benefits $[51,86]$. A Chinese consensus proposes that mild COVID-19 symptoms should be treated with HDIVC $(50-100 \mathrm{mg} / \mathrm{kg} / \mathrm{d})$ to improve $\mathrm{P} / \mathrm{F}$ ratio and prevent cytokine storm [87]. UK Chelsea and Westminster hospital ICU stratification and treatment protocol contains anticoagulants plus $1 \mathrm{~g}$ twice a day enteral or IV Vitamin C since admission [88].

\section{Conclusions}

Early nutritional support seems to be an augmented factor for better outcomes in COVID-19 and vitamin C can offer a strong alternative. HDIVC is well tolerated and apparently has a positive expectation, even though some studies failed to provide incontrovertible evidence for its use by achieving their primary outcomes. VC's position can be ubiquitous as it is cost effective and seems to improve the disease's parameters. Protocols introducing the idea of estimating VC deficit should be the springboard for RCTs to identify whether a COVID-19 patient with optimal VC levels could profit from an early administration and whether he could be rescued with HDIVC. The level of VC benefit on the management of COVID-19 is still to be estimated but in our point of view, the incorporation of HDIVC in hospital protocols for critically ill patients can be immediate. Results from ongoing trials will provide more information about its safety, possible clinical outcomes and new prospects such as the combination of $\mathrm{VC}$ with other antimicrobial substances.

\section{References}

1. Cossarizza A, De Biasi S, Guaraldi G, et al. SARS-CoV-2, the virus that causes COVID-19: Cytometry and the new challenge for global health. Cytometry A 2020;97:340-3.

2. Siemieniuk RA, Bartoszko JJ, Ge L, et al. Drug treatments for covid-19: living systematic review and network meta-analysis. BMJ 2020;370:m2980.

3. Our World in Data [Internet], Coronavirus (COVID-19) vaccinations. Dec 13, 2020 - Feb 15, 2021. Available from: https://ourworldindata.org/covid-vaccinations

4. Yuan P, Ai P, Liu Y, et al. Safety, tolerability, and immunogenicity of COVID-19 vaccines: A systematic review and meta-analysis. medRxiv 2020;2020.11.03.20224998.

5. Giamarellos-Bourboulis EJ, Netea MG, Rovina N, et al. Complex immune dysregulation in COVID-19 patients with severe respiratory failure. Cell Host Microbe 2020;27:9921000.e3.

6. Huang I, Pranata R, Lim MA, et al. C-reactive protein, procalcitonin, D-dimer, and ferritin in severe coronavirus disease2019: a meta-analysis. Ther Adv Respir Dis 2020;14. Online ahed of print.

7. Alamdari DH, Moghaddam AB, Amini S, et al. Application of methylene blue -vitamin $\mathrm{C}-\mathrm{N}$-acetyl cysteine for treatment of critically ill COVID-19 patients, report of a phase-I clinical trial. Eur J Pharmacol 2020;885:173494.

8. Zhang J, Rao X, Li Y, et al. Pilot trial of high-dose vitamin C in critically ill COVID-19 patients. Ann Intensive Care 2021;11:5.
9. Hiedra R, Lo KB, Elbashabsheh M, et al. The use of IV vitamin C for patients with COVID-19: a case series. Expert Rev Anti Infect Ther 2020;18:1259-61.

10. Zhao B, Ling Y, Li J, et al. Beneficial aspects of high dose intravenous vitamin $\mathrm{C}$ on patients with COVID-19 pneumonia in severe condition: a retrospective case series study. Ann Palliat Med 2021;10:1599-609.

11. JamaliMoghadamSiahkali S, Zarezade B, Koolaji S, et al. Safety and effectiveness of high-dose vitamin $\mathrm{C}$ in patients with COVID-19: a randomized open-label clinical trial. Eur J Med Res 2021;26:20.

12. Burugu HR, Kandi V, Kutikuppala LVS, Suvvari TK. Activities of serum ferritin and treatment outcomes among COVID-19 patients treated with vitamin c and dexamethasone: An uncontrolled single-center observational study. Cureus 2020;12:e11442.

13. Kumari P, Dembra S, Dembra P, et al. The role of vitamin C as adjuvant therapy in COVID-19. Cureus 2020;12:e11779.

14. Thomas S, Patel D, Bittel B, et al. Effect of high-dose zinc and ascorbic acid supplementation vs usual care on symptom length and reduction among ambulatory patients with SARSCoV-2 infection: The COVID A to $\mathrm{Z}$ randomized clinical trial. JAMA Netw Open 2021;4:e210369.

15. Arvinte C, Singh M, Marik PE. Serum levels of vitamin C and vitamin D in a cohort of critically ill COVID-19 patients of a north American community hospital intensive care unit in May 2020: A pilot study. Med Drug Discov 2020;8:100064.

16. Chiscano-Camón L, Ruiz-Rodriguez JC, Ruiz-Sanmartin A, et al. Vitamin C levels in patients with SARS-CoV-2-associated acute respiratory distress syndrome. Crit Care 2020;24:522.

17. Pincemail J, Cavalier E, Charlier C, et al. Oxidative stress status in COVID-19 patients hospitalized in intensive care unit for severe pneumonia. A pilot study. Antioxidants (Basel) 2021;10:257.

18. Frei B, England L, Ames BN. Ascorbate is an outstanding antioxidant in human blood plasma. Proc Natl Acad Sci USA 1989;86:6377-81.

19. Tsukaguchi H, Tokui T, Mackenzie B, et al. A family of mammalian $\mathrm{Na}+$-dependent L-ascorbic acid transporters. Nature 1999;399:70-5.

20. Asard H, May J, Smirnoff N. Vitamin C: Its functions and biochemistry in animals and plants. Chichester Taylor \& Francis; 2004.

21. Jovic TH, Ali SR, Ibrahim N, et al. Could vitamins help in the fight against COVID-19. Nutrients 2020;12:E2550.

22. Levine M. New concepts in the biology and biochemistry of ascorbic acid. N Engl J Med 1986;314:892-902.

23. Infusino F, Marazzato M, Mancone M, et al. Diet supplementation, probiotics, and nutraceuticals in SARS-CoV-2 infection: A scoping review. Nutrients 2020;12:E1718.

24. Kim HJ, Lee SI, Lee DH, et al. Ascorbic acid synthesis due to L-gulono-1,4-lactone oxidase expression enhances NO production in endothelial cells. Biochem Biophys Res Commun 2006;345:1657-62.

25. Jackson TS, Xu A, Vita JA, Keaney JF. Ascorbate prevents the interaction of superoxide and nitric oxide only at very high physiological concentrations. Circ Res 1998;83:916-22.

26. Carr A, Frei B. Does vitamin $C$ act as a pro-oxidant under physiological conditions. FASEB J 1999;13:1007-24.

27. Smith AR, Visioli F, Hagen TM. Vitamin C matters: increased oxidative stress in cultured human aortic endothelial cells without supplemental ascorbic acid. FASEB J 2002;16:1102-4. 28. Tyml K, Li F, Wilson JX. Septic impairment of capillary blood 
flow requires nicotinamide adenine dinucleotide phosphate oxidase but not nitric oxide synthase and is rapidly reversed by ascorbate through an endothelial nitric oxide synthase-dependent mechanism. Crit Care Med 2008;36:2355-62.

29. Fisher BJ, Kraskauskas D, Martin EJ, et al. Mechanisms of attenuation of abdominal sepsis induced acute lung injury by ascorbic acid. Am J Physiol Lung Cell Mol Physiol 2012;303:L20-32.

30. Iddir M, Brito A, Dingeo G, et al. Strengthening the immune system and reducing inflammation and oxidative stress through diet and nutrition: considerations during the COVID19 crisis. Nutrients 2020;12:E1562.

31. de la Fuente M, Ferrández MD, Burgos MS, et al. Immune function in aged women is improved by ingestion of vitamins C and E. Can J Physiol Pharmacol 1998;76:373-80.

32. Goldschmidt MC, Masin WJ, Brown LR, Wyde PR. The effect of ascorbic acid deficiency on leukocyte phagocytosis and killing of actinomyces viscosus. Int $\mathrm{J}$ Vitam Nutr Res 1988;58:326-34.

33. Nungester WJ, Ames AM. The relationship between ascorbic acid and phagocytic activity. J Infect Dis 1948;83:50-4.

34. Johnston CS, Huang SN. Effect of ascorbic acid nutriture on blood histamine and neutrophil chemotaxis in guinea pigs. J Nutr 1991;121:126-30.

35. Johnston CS, Martin LJ, Cai X. Antihistamine effect of supplemental ascorbic acid and neutrophil chemotaxis. J Am Coll Nutr 1992;11:172-6.

36. Mohammed BM, Fisher BJ, Kraskauskas D, et al. Vitamin C: a novel regulator of neutrophil extracellular trap formation. Nutrients 2013;5:3131-51.

37. Czaikoski PG, Mota JM, Nascimento DC, et al. Neutrophil extracellular traps induce organ damage during experimental and clinical sepsis. PLoS On. 2016;11:e0148142.

38. Prinz W, Bortz R, Bregin B, Hersch M. The effect of ascorbic acid supplementation on some parameters of the human immunological defence system. Int J Vitam Nutr Res 1977;47:248-57.

39. Heyland DK, Dhaliwal R, Suchner U, Berger MM. Antioxidant nutrients: a systematic review of trace elements and vitamins in the critically ill patient. Intensive Care Med 2005;31:327-37.

40. Cárcamo JM, Bórquez-Ojeda O, Golde DW. Vitamin C inhibits granulocyte macrophage-colony-stimulating factorinduced signaling pathways. Blood 2002;99:3205-12.

41. Gao YL, Lu B, Zhai JH, et al. The parenteral vitamin C improves sepsis and sepsis-induced multiple organ dysfunction syndrome via preventing cellular immunosuppression. Mediators Inflamm 2017;2017:4024672.

42. Fisher BJ, Seropian IM, Kraskauskas D, et al. Ascorbic acid attenuates lipopolysaccharide-induced acute lung injury. Crit Care Med 2011;39:1454-60.

43. Cárcamo JM, Pedraza A, Bórquez-Ojeda O, Golde DW. Vitamin C suppresses TNF alpha-induced NF kappa B activation by inhibiting I kappa B alpha phosphorylation. Biochemistry 2002;41:12995-3002.

44. Mikirova N, Riordan N, Casciari J. Modulation of Cytokines in Cancer Patients by Intravenous Ascorbate Therapy. Med Sci Monit 2016;22:14-25.

45. Ma S, Sun S, Li J, et al. Single-cell transcriptomic atlas of primate cardiopulmonary aging. Cell Res 2021;31:415-32.

46. Anderson TJ, Uehata A, Gerhard MD, et al. Close relation of endothelial function in the human coronary and peripheral circulations. J Am Coll Cardiol 1995;26:1235-41.
47. Lykkesfeldt J, Poulsen HE. Is vitamin C supplementation beneficial? Lessons learned from randomised controlled trials. $\mathrm{Br}$ J Nutr 2010;103:1251-9.

48. Levine M, Rumsey SC, Daruwala R, et al. Criteria and recommendations for vitamin C intake. JAMA 1999;281:1415-23.

49. Gey KF, Moser UK, Jordan P, et al. Increased risk of cardiovascular disease at suboptimal plasma concentrations of essential antioxidants: an epidemiological update with special attention to carotene and vitamin C. Am J Clin Nutr 1993;57:S787-97.

50. Jacob RA, Skala JH, Omaye ST. Biochemical indices of human vitamin C status. Am J Clin Nutr 1987;46:818-26.

51. Caccialanza R, Laviano A, Lobascio F, et al. Early nutritional supplementation in non-critically ill patients hospitalized for the 2019 novel coronavirus disease (COVID-19): Rationale and feasibility of a shared pragmatic protocol. Nutrition 2020;74:110835.

52. Fowler AA, Syed AA, Knowlson S, et al. Phase I safety trial of intravenous ascorbic acid in patients with severe sepsis. J Transl Med 2014;12:32.

53. Hudson EP, Collie JT, Fujii T, et al. Pharmacokinetic data support 6-hourly dosing of intravenous vitamin $\mathrm{C}$ to critically ill patients with septic shock. Crit Care Resusc 2019;21:236-42.

54. de Grooth HJ, Manubulu-Choo WP, Zandvliet AS, et al. Vitamin C pharmacokinetics in critically ill patients: A randomized trial of four IV regimens. Chest 2018;153:1368-77.

55. Levine M, Conry-Cantilena C, Wang Y, et al. Vitamin C pharmacokinetics in healthy volunteers: evidence for a recommended dietary allowance. Proc Natl Acad Sci USA 1996;93:3704-9.

56. Sasazuki S, Sasaki S, Tsubono Y, et al. Effect of vitamin C on common cold: randomized controlled trial. Eur J Clin Nutr 2006;60:9-17.

57. Van Straten M, Josling P. Preventing the common cold with a vitamin C supplement: a double-blind, placebo-controlled survey. Adv Ther 2002;19:151-9.

58. Johnston CS, Barkyoumb GM, Schumacher SS. Vitamin C supplementation slightly improves physical activity levels and reduces cold incidence in men with marginal vitamin $\mathrm{C}$ status: a randomized controlled trial. Nutrients 2014;6:2572-83.

59. Gorton HC, Jarvis K. The effectiveness of vitamin C in preventing and relieving the symptoms of virus-induced respiratory infections. J Manipulative Physiol Ther 1999;22:530-3.

60. Audera C, Patulny RV, Sander BH, Douglas RM. Mega-dose vitamin $\mathrm{C}$ in treatment of the common cold: a randomised controlled trial. Med J Aust 2001;175:359-62.

61. Hemilä H, Chalker E. Vitamin C for preventing and treating the common cold. Cochrane Database Syst Rev 2013 CD000980.

62. Lopez BS, Yamamoto M, Utsumi K, et al. A clinical pilot study of lignin--ascorbic acid combination treatment of herpes simplex virus. In Vivo 2009;23:1011-6.

63. Müller F, Svardal AM, Nordoy I, et al. Virological and immunological effects of antioxidant treatment in patients with HIV infection. Eur J Clin Invest 2000;30:905-14.

64. Mikirova N, Hunninghake R. Effect of high dose vitamin C on Epstein-Barr viral infection. Med Sci Monit 2014;20:725-32.

65. Galley HF, Howdle PD, Walker BE, Webster NR. The effects of intravenous antioxidants in patients with septic shock. Free Radic Biol Med 1997;23:768-74.

66. Carr AC, Rosengrave PC, Bayer S, et al. Hypovitaminosis C and vitamin $\mathrm{C}$ deficiency in critically ill patients despite recommended enteral and parenteral intakes. Crit Care 2017;21:300. 
67. Pontes-Arruda A, Aragão AM, Albuquerque JD. Effects of enteral feeding with eicosapentaenoic acid, gamma-linolenic acid, and antioxidants in mechanically ventilated patients with severe sepsis and septic shock. Crit Care Med 2006;34:232533.

68. Wani SJ, Mufti SA, Jan RA, et al. Combination of vitamin C, thiamine and hydrocortisone added to standard treatment in the management of sepsis: results from an open label randomised controlled clinical trial and a review of the literature. Infect Dis (Lond) 2020;52:271-8.

69. Fujii T, Luethi N, Young PJ, et al. Effect of vitamin C, hydrocortisone, and thiamine vs hydrocortisone alone on time alive and free of vasopressor support among patients with septic shock: The VITAMINS randomized clinical trial. JAMA. 2020 02 4;323:423-31.

70. Colunga Biancatelli RML, Berrill M, Catravas JD, Marik PE. Quercetin and vitamin C: An experimental, synergistic therapy for the prevention and treatment of SARS-CoV-2 related disease (COVID-19). Front Immunol 2020;11:1451.

71. Li R, Wu K, Li Y, et al. Integrative pharmacological mechanism of vitamin $\mathrm{C}$ combined with glycyrrhizic acid against COVID-19: findings of bioinformatics analyses. Brief Bioinform 2021;22:1161-74.

72. Fowler AA, Truwit JD, Hite RD, et al. Effect of vitamin C infusion on organ failure and biomarkers of inflammation and vascular injury in patients with sepsis and severe acute respiratory failure: The CITRIS-ALI randomized clinical trial. JAMA 2019322:1261-70.

73. Li C, Bo L, Liu W, et al. Enteral immunomodulatory diet (omega-3 fatty acid, $\gamma$-linolenic acid and antioxidant supplementation) for acute lung injury and acute respiratory distress syndrome: An updated systematic review and meta-analysis. Nutrients 2015;7:5572-85.

74. Dushianthan A, Cusack R, Burgess VA, et al. Immunonutrition for adults with ARDS: Results from a Cochrane systematic review and meta-analysis. Respir Care 2020;65:99-110.

75. Li J. Evidence is stronger than you think: a meta-analysis of vitamin C use in patients with sepsis. Crit Care 2018; 22:258.
76. Hemilä H, Chalker E. Vitamin C can shorten the length of stay in the ICU: A meta-analysis. Nutrients 2019;11:E708.

77. Hemilä H, Chalker E. Vitamin C may reduce the duration of mechanical ventilation in critically ill patients: a meta-regression analysis. J Intensive Care 2020;8:15.

78. Farjana M, Moni A, Sohag AAM, et al. Repositioning vitamin $\mathrm{C}$ as a promising option to alleviate complications associated with COVID-19. Infect Chemothe. 2020;52:461-77.

79. Morelli MB, Gambardella J, Castellanos V, et al. Vitamin C and cardiovascular disease: An update. Antioxidants (Basel) 2020;9:E1227.

80. Kashiouris MG, L'Heureux M, Cable CA, et al. The emerging role of vitamin C as a treatment for sepsis. Nutrients 2020;12:E292.

81. Waqas Khan HM, Parikh N, Megala SM, Predeteanu GS. Unusual early recovery of a critical COVID-19 patient after administration of intravenous vitamin C. Am J Case Rep 2020;21:e925521.

82. Douedi S, Miskoff J. Novel coronavirus 2019 (COVID-19): A case report and review of treatments. Medicine (Baltimore) 2020;99:e20207.

83. Cossey LN, Rahim F, Larsen CP. Oxalate nephropathy and intravenous vitamin C. Am J Kidney Dis 2013;61:1032-5.

84. Fontana F, Cazzato S, Giovanella S, et al. Oxalate nephropathy caused by excessive vitamin $\mathrm{C}$ administration in 2 patients with COVID-19. Kidney Int Rep 2020;5:1815-22.

85. Front Line COVID-19 Critical Care Alliance Group. MATH+ Hospital Treatment Protocol for COVID-19. 2020, Dec 14 update.

86. Jin YH, Cai L, Cheng ZS, et al. A rapid advice guideline for the diagnosis and treatment of 2019 novel coronavirus (2019$\mathrm{nCoV}$ ) infected pneumonia (standard version). Mil Med Res 2020;6;7:4.

87. Shanghai Clinical Treatment Expert Group for COVID-19. Comprehensive treatment and management of corona virus disease 2019: expert consensus statement from Shanghai. Chin J Infect Dis 2020;38:E016.

88. Vizcaychipi MP, Shovlin CL, McCarthy A, et al. Development and implementation of a COVID-19 near real-time traffic light system in an acute hospital setting. Emerg Med J 2020;37:630-6. 